\title{
Attitude of Farmers towards Cost-Sharing in the Second National Fadama Development Project (NFDP-II): The Case of Kogi State of Nigeria
}

\author{
A. E. Agwu' ${ }^{1^{*}}$ and H. O. Abah ${ }^{2}$ \\ ${ }^{1}$ Department of Agricultural Extension \\ University of Nigeria, Nsukka, Enugu State, Nigeria \\ Email: agwuekwe@hotmail.com \\ ${ }^{2}$ Department of Livestock and Pest Control Services, \\ Federal Ministry of Agriculture and Water Resources Lokoja \\ Kogi State, Nigeria \\ Email: abahhellen@yahoo.com
}

\begin{abstract}
This paper highlights the attitude of farmers towards the Second National Fadama Development Project (NFDP-II) implementation at the local level in Nigeria. The fadama II project focuses on government - farmer partnerships in the funding of agricultural enterprises with the aim of achieving sustainable and stable funding for agricultural development. The sample for the study was made up of male and female Fadama beneficiaries selected through multistage sampling from the fadama resource users groups (FRUGs) in Lokoja and Idah LGAs of Kogi State. The findings indicated that the majority (51.5\%) of the respondents were in their productive years. The results show that the majority of the farmers had favourable attitude towards cost - sharing of the fadama II programme. However, the level of farmers' participation in the planning, implementation and monitoring activities were very low except in the areas of financial management, maintenance of fadama investments and proffering conflict mitigation measures. The findings further indicates that late disbursement of funds from the African Development Bank (ADB), difficulty in collecting money from some farmers/high cost of administration, insufficient credit availability and the tendency of highly placed individuals/politicians to hijack the programme by registering personal resource user groups (FRUGs)/fadama community associations (FCAs) were problems militating against the effective implementation of the project. The study concludes that there is great need to specifically target vulnerable sub-groups such as widows, the elderly, castes and marginal fadama users through an inclusive participatory planning process to avoid situations of elite capture and conflicts in the on-going Fadama III project.
\end{abstract}

Key words: Fadama II Project; Cost-Sharing; Community Demand Driven (CDD) Approach; Participation; Attitude. 


\section{INTRODUCTION}

Agricultural development aimed at poverty reduction requires technologies, organizational and institution innovations. The recent emphasis on strengthening the demand for agricultural service provision and the call for a separation of responsibilities for policy making, funding and implementation have resulted in alternative funding mechanisms for agricultural research and development (R \& D) at national and local levels (Heemskerk and Wennink 2005). This paradigm shift involving counterpart funding or cost sharing is a new financing arrangement in fadama agriculture in Nigeria.

The fadama development project is one of the Nigeria's agricultural policies designed to increase food production for her teeming and growing population. The first phase of the project, named fadama I started in 1990 through the collaboration of the Federal Government of Nigeria and the World Bank. This is in realization of the fact that fadama potentials had a high capacity of reducing the negative effect of rudimentary and small holder rain fed agriculture on the teeming population in rural Nigeria.

According to Project Coordinating Unit - National Fadama Development Office (PCUNFDO) (2005) and the World Bank (2003a) fadama (i.e. a Hausa derivative) refers to irrigable land, flood plains and low lying areas underlined by shallow aquifers found along Nigeria water system. The fadama system of agriculture is not new in Nigeria as it has been a major preoccupation of the peasant farmers in the northern part of Nigeria who grew mainly vegetables, sugar-cane and fruits during dry seasons through irrigation. There was however a low utilization of the fadama resources which has been observed to account partly for the poor performance of Nigeria's agricultural sector (World Bank, 2003a).

The various attempts by Nigerian government in initiating agricultural programmes aimed at achieving food security have failed due mainly to inadequate funding and in some cases, lack of commitment in implementing the agreement on such programmes. Agwu and Chukwuone (2002) have in this regard stated that the agricultural development programmes, for example, suffered serious setbacks due to poor funding and funding instability following the expiration of the World Bank counterpart funding arrangements.

Several policies involving agricultural funding such as the River Basin Development Authority (RBDA), the Operation Feed the Nation (OFN), the National Accelerated Food Production Programmes (NAFPP) and the Agricultural Development Projects (ADPs) have been embarked upon using different approaches of funding and implementation. In these programmes, agricultural loans and grants at low and sometimes no interest rates were maintained. Agwu and Ugwu (2008) pointed out that loans were given to the farmers involved in the National Special Programme on Food Security (NSPFS) of 2003/2004 without interest and that inputs such as fertilizers, herbicides, insecticides and improved seeds were given to them at subsidized rates.

Many agricultural experts, researches and international donor organizations have seriously condemned this type of total public sector approach to the funding and implementation of agricultural projects in Nigeria and other developing countries. According to their observations, the approach has been mainly responsible for the failures and wastages so far recorded on agricultural projects. The new cost-sharing strategy aimed at ensuring a demanddriven agricultural technology transfer and services is expected to bring about desirable changes especially in developing countries such as Nigeria. Cost sharing in agriculture involves government-farmer partnership in the funding of agricultural extension services with the aim of achieving sustainable and stable funding for agricultural technology delivery. It has been described by Chukwuone, Agwu and Ozor (2006) as a tenable privatization policy towards 
Journal of Agricultural Extension

Vol. 13 (2) December 2009

providing adequate and stable funding of agricultural services in Nigeria. According to Heemskerk and Wennink (2005) local cost-sharing and co-financing arrangements aim at strengthening collaboration through joint responsibility by building on the comparative advantage of different stakeholders. In a study carried out by Chukwone et. al. (2006) on cost sharing of agricultural technology transfer in Nigeria, it was found that the majority of the farmers and extension staff in all the six geopolitical zones had positive perception towards cost sharing of agricultural technology transfer. The findings of another study by Agwu (2005) also showed that majority of farmers have strong positive attitude towards the fadama I project in Okigwe agricultural zone of Imo state. The fadama I project was the first attempt to share cost of programme implementation at the local level in Nigeria, involving 18 states of the country with the World Bank as a major co-financier and $10 \%$ counterpart funding by beneficiaries.

\section{Operational Framework}

The fadama II project is implemented using the Community Demand Driven (CDD) approach which strongly emphasizes stakeholders' participation at the community level to develop participatory and socially inclusive Local Development Plans (LDPs) which provide the basis for support and funding under the project (PCU-NFDO, 2005). This paradigm shift from the traditional public sector dominated/supply led development approaches of the past to a private sector-led, demand-driven strategy ensures full guidance of participating farmers through several institutional structures. The various fadama resource users, including crop farmers, pastoralists, fishermen and women and on and off farm entrepreneurs, operating through their respective fadama resource user groups (FRUGs) and their apex bodies, the Fadama Community Associations (FCAs), agree on a consensus on how to use the common resources for their mutual advantage. Through this process, communities decide on the advisory and infrastructures they need to enable them attain development goals they set for themselves based on their efforts. The consensus so reached are articulated in Community Development Plans (CDPs) drawn at the level of the Fadama Community Associations (FCAs).

The major functions of the fadama development offices at federal, states and local government area levels include planning, advisory, monitoring, management and supervision. However, facilitators are hired by the state fadama development team (SFDT) to organize the fadama users groups and guide them through the intensive processes of decision making using a wide range of participative techniques (World Bank, 2003b). The labour, materials available and other resources of the farmers are monetized into the $10 \%$ paid by the farmers during the cost-sharing arrangement and agreement.

According to World Bank (2003b), success stories have been achieved using this approach in India, Pakistan, Argentina and Kenya. However, in Nigeria, even though the fadama I project recorded some measure of success, certain limitations and its restriction to crop production only, brought about some problems of conflicts (Onoja, 2004). These conflicts which were mainly between the farmers and other fadama users especially pastoralists and fishermen over stock routes, crop destruction and encroachment led to the initiative of fadama II. The fadama II programme fosters participation of all the other areas of farming. The project development document prepared by African Development Fund (ADF) of the African Development Bank (ADB) in collaboration with the Federal Republic of Nigeria (FRN) of 2004 is an adoption with moderations of the structural arrangements and implementation procedures planned during and after the lessons from fadama I. It has long term project development objectives as outlined by the World Bank (2003a). These include to: 
1. Sustainably increase the income of fadama users;

2. Empower communities to take charge of their development agenda and

3. Reduce conflict between fadama users.

Kogi state is one of the states under ADB sponsorship. The other five states covered by the ADB are: Borno, Jigawa, Kastina, Kwara and Plateau. All the six (6) states handled by ADB are referred to as non-core fadama I states except Jigawa. According to the ADF (2004), the states were selected on the basis of a comprehensive set of criteria of:

(a) Written proposed action plan for both upstream and downstream post-harvest activities.

(b) A written commitment for regular payment of counterpart fund deducted at source (at the ministry of finance).

(c) Evidence of viable and active Fadama Resource Users Groups or economic groups;

(d) Evidence of the existence of conflict management committees

(e) Compilation of a detailed assessment of existing fadama infrastructure, and

(f) A record of fadama loan recovery rate of $75 \%$.

Kogi state has been reported as having met all these eligibility criteria set for selection of participating state including the loan-recovery rate of $75 \%$ under fadama I project, an acceptable staff strength of the Agricultural Development Programme (ADP) as well as the inclusion of farmers and private sector representatives on the ADP Executive Committee (ADPEC) among others required (Onoja, 2004). Out of the 21 LGAs in the state, 10 of them were earmarked for the project. They include: Ibaji, Idah, Olamaboro, Omalla, Bassa, Kogi, Lokoja, Adavi, Mopamuro and Kabba-bunu LGAs. Kogi State possesses all the weather conditions that make it a fadama area.

\section{Purpose and Objectives}

This study therefore investigates the attitude of fadama II farmers in Kogi state towards the cost-sharing mechanism of Fadama II project. The specific objectives include to:

1. highlight the socio-economic characteristics of the Fadama farmers in the state;

2. ascertain the attitude of the Fadama farmers towards the cost-sharing mechanism;

3. ascertain the level of participation of Fadama farmers in the planning, implementation and monitoring of the Fadama II activities, and

4. identify the problems militating against the effective implementation of the NFDP II in the state. 
Journal of Agricultural Extension

Vol. 13 (2) December 2009

\section{METHODOLOGY}

\section{Area of Study}

The study was carried out in Kogi State of Nigeria. According to Kogi State ADP (1998), the state lies between Longitudes $5^{0} 18^{1} \mathrm{E}$ to $7^{0} 49^{1} \mathrm{E}$ and Latitudes $6^{0} 31^{1} \mathrm{~N}$ and $8^{0} 42^{1} \mathrm{~N}$. It is centrally located in between the North and South of the country sharing boundaries with eight (8) states. The state is bounded in the north by the states of Niger, Plateau, Nassarawa and the Federal Capital Territory (FCT); in the South by Enugu and Edo states, and in the West by Ekiti and Ondo states. The estimated population of the State is $3,278,487$ persons (National Population Commission, 2006) with an estimated 187,000 fadama farmers (Kogi State Fadama Development Office (KFDO), 2007).

Popularly known as the confluence state, it has the two main rivers- Niger and Benue running through it and meeting at Lokoja, its' capital. Other rivers and wetlands exist in the state due to the hilly nature of some parts. The climate oscillates between the wet and dry season with a daily temperature of between $24^{\circ} \mathrm{c}-27^{\circ} \mathrm{c}$, while annual mean rainfall is between $1250-$ $1700 \mathrm{~mm}$ spreading over eight (8) months. These conditions make the area favourable and suitable for extensive practice of agriculture. The vegetation of Kogi State is the mixed savannah and forest types and the predominant crops grown include maize, rice, guinea corn, millet, yam, cassava, sweet potatoes, cowpea, groundnut, soybean, beniseed and vegetables. A few cash crops such as cocoa, coffee, kola-nuts, timber, banana and plantains are also well grown. Considerable livestock activities comprising mainly Fulani cattle grazing, small ruminant and poultry rearing are prevalent, while fishing is generally predominant.

The ten (10) program sites for the fadama project involve communities from all the three senatorial districts of the state. This study focused on two LGAs, namely; Idah and Lokoja LGAs. The choice of these LGAs is based on the high population of Fadama interest groups in the area.

\section{Study Population and Sampling Techniques}

The population of the study comprised all the male and female fadama farmers in Lokoja and Idah Local government areas of the State. According to Kogi State Fadama Development Office (KFDO) (2007) there are 3,980 male and female Fadama farmers distributed in 5 Fadama Community Associations (FCAs) made up of 97 Fadama Resource User Groups (FRUGs) and 4 FCAs of made up of 140 FRUGs in Lokoja and Idah LGAs, respectively.

Multistage random sampling techniques were used in selecting the respondent farmers. In the first stage a total of four (4) out of nine (9) FCAs in Idah and Lokoja LGAs were randomly selected. In the second stage ten (10) each out of 140 FRUGs and 97 FRUGs from Idah and Lokoja respectively, were randomly selected making a total of 20 FRUGs. In the third stage five (5) Fadama farmers from each of the twenty FRUG were randomly selected, giving a total of 100 respondents for the study, from the two LGAs.

\section{Data Collection}

Data for the study were collected from respondents using structured interview schedule. In order to obtain a quantitative measure of respondents' perception on cost sharing in fadama II Project, (objective 2), rating scales with a pool of positive and negative statements were framed through review of literature and Fadama II project documents. Four-point Likert scale with values of strongly agree $=4$; agree $=3$; disagree $=2$; strongly disagree $=1$ was used to determine each respondent's level of agreement or disagreement with the statements. A cut-off mark of 2.5 was used to select statements which were perceived favourably by the respondents. For all the positive statements a mean score of $\geq 2.5$ depicts a favourable statement with regard 
to attitude of farmers towards cost sharing in fadama II. Also for all negative statements (scoring of all negative statements used to ascertain the attitude of farmers towards cost sharing in fadama II project were reversed) a mean score of $\geq 2.5$ shows a favourable statement with regard to the attitude of farmers towards cost sharing. To determine the respondents' perceived level of participation in the fadama II project activities, the respondents were presented with four main types of participation namely: contractual, consultative, collaborative and collegial (Biggs, 1989a). Respondents were then asked to score the operational components of fadama II project on the basis of their participation using a four-point Likert- type scale weighted as follows: contractual $=1$; consultative $=2$; collaborative $=3$; collegial $=4$. Respondents mean scores were then computed for each operational activity under the fadama project. These were used to estimate the farmers' levels of participation in the project using the following decision rules:

$$
\begin{aligned}
& \bar{X} 1.00-1.49 \text { (Contractual) } \\
& \bar{x} 1.50-2.49 \text { (Consultative) } \\
& \bar{x} 2.50-3.49 \text { (Collaborative) } \\
& \bar{x} 3.50-4.0 \quad \text { (Collegial). }
\end{aligned}
$$

In section $D$, to identify the problems militating against the effective implementation of the NFDP in Kogi State, 20 items depicting problems facing the fadama project were framed again from literature review. A three-point Likert scale with values of not serious $=1$, serious $=$ 2 ; and very serious $=3$ was used to determine the respondents' perception of the problems of fadama II project. A cut-off mark of 2 was used to select the statements that were perceived as most serious, serious and not serious. All the statements with the mean values of (above) $\geq 2$ were regarded as major constraints while mean values of (below) $\leq 2$ were regarded as minor constraints to the effective implementation of the project.

\section{Data analysis}

Data collected were analyzed using descriptive statistics such as means, frequency, percentage and standard deviation. Objective one was analyzed using percentages and frequency. Objective two and three were analyzed using mean scores. Objective four were analyzed using mean scores and standard deviation.

\section{RESULTS AND DISCUSSION}

\section{Socio- economic Characteristics of Respondents}

Table 1 shows that majority (78.3\%) of the fadama farmers were between 31 and 50 years old. The average age of the respondents was about 45 years, indicating that the majority of the participating farmers belong to the young and middle aged group, which is an advantage in learning new technologies (Agwu, 2004). Slightly more than $(51.5 \%)$ half of the respondents were males. This small gender gap of only $3.0 \%$ is a strong indication that the participation of women in agricultural programmes in Nigeria in on the increase. Majority $(75.3 \%)$ of them were married, which is an indication that fadama farming will be sustainable as it involves responsible people who can be trusted in cost sharing programme. Level of formal education was not very encouraging as up to $35.1 \%$ of the farmers had no formal education, while $26.8 \%$ had primary school education. According to Agwu (2004) education has been shown to be a factor in the adoption of yields increasing modern farm practices. 


\section{Journal of Agricultural Extension}

Vol. 13 (2) December 2009

The table further shows that the majority $(55.0 \%)$ of the respondents had family size of between 6-10 members. The implication of this is that more family labour will be readily available since relatively large household size has been reported by Igben (1988) to be an obvious advantage in terms of farm labour supply. Analysis of occupational status of the respondents showed that $41.2 \%$ of the respondents were primarily engaged in farming, while $20.6 \%$ were engaged in trading and civil service, respectively. The table also shows that $76.3 \%$ of farmers had above10 years of farming experience. This shows that a good number of the respondents had long farming experience. This could increase their level of acceptance of new ideas as means of overcoming their production constraints (Agwu, 2004) and hence serve as an advantage for increased productivity of fadama farmers. Analysis of annual income data indicates that the average income of farmers before joining fadama programme was $N 32$, 808.51. Average income of farmers from fadama in 2004 was N28, 887.32 while in 2005, it was $\mathbb{N 3 5}, 445.7$ and $\$ 44,630.43$ in 2006 . The estimated mean annual income from all investments was ${ }^{2}$ 97, 946.81. This shows that there is a successive increase in their income annually from fadama farming. The difference in annual income between when they had not joined fadama and after joining the programme was quite high. This shows improvement in the income status of the farmers as a result of this project. It is most likely that increase in the annual income of these farmers will bring about effective cost sharing and sustainability of the fadama programme. 
TABLE 1: Summary of socio-economic characteristics of respondents

\begin{tabular}{|c|c|c|c|}
\hline Variables & Frequency & Percentage & $\bar{x}$ (Mean) \\
\hline \multicolumn{4}{|l|}{ Sex } \\
\hline Male & 50 & 51.5 & \\
\hline Female & 47 & 48.5 & \\
\hline \multicolumn{4}{|l|}{ Age } \\
\hline $21-30$ & 15 & 15.5 & 45.44 \\
\hline $31-40$ & 50 & 51.5 & \\
\hline 41050 & 26 & 26.8 & \\
\hline $51-60$ & 3 & 3.1 & \\
\hline 61 and above & 3 & 3.1 & \\
\hline \multicolumn{4}{|l|}{ Marital status } \\
\hline Single & 4 & 4.1 & \\
\hline Married & 73 & 75.3 & \\
\hline Divorced & 4 & 4.1 & \\
\hline Widowed/widower & 16 & 16.5 & \\
\hline \multicolumn{4}{|l|}{ Level of formal education } \\
\hline No formal education & 34 & 35.1 & \\
\hline Primary education & 26 & 26.8 & \\
\hline Secondary education & 26 & 26.8 & \\
\hline Tertiary education & 11 & 11.3 & \\
\hline \multicolumn{4}{|l|}{ Family size (members) } \\
\hline $1-5$ members & 26 & 25.8 & \\
\hline 6-10 members & 55 & 56.5 & \\
\hline 10-15 members & 16 & 16.5 & \\
\hline \multicolumn{4}{|l|}{ Major occupation of farmers } \\
\hline Driving and handwork & 17 & 17.5 & \\
\hline Farming & 40 & 41.2 & \\
\hline Trades & 20 & 20.6 & \\
\hline Civil servants & 20 & 20.6 & \\
\hline \multicolumn{4}{|l|}{ Years of farming experiences } \\
\hline $6-10$ years & 23 & 23.7 & \\
\hline $11-15$ years & 35 & 36.3 & \\
\hline $16-20$ years & 18 & 18.6 & \\
\hline $21-25$ years & 8 & 8.3 & \\
\hline $26-30$ years & 6 & 6.2 & \\
\hline $31-35$ years & 2 & 2.1 & \\
\hline \multicolumn{4}{|l|}{ Annual income of farmers } \\
\hline $\begin{array}{l}\text { Income before joining fadama } \\
\text { programme }\end{array}$ & 94 & & 32808.51 \\
\hline Income from fadama in 2006 & 92 & & 44630.43 \\
\hline Income from fadama in 2005 & 79 & & 35455.70 \\
\hline Income from fadama in 2004 & 71 & & 28887.32 \\
\hline Annual income from all investments & 94 & & 97946.81 \\
\hline
\end{tabular}


Journal of Agricultural Extension

Vol. 13 (2) December 2009

\section{Attitudes of Fadama Farmers towards Cost Sharing in Fadama II Project}

Table 2 shows the distribution of the mean scores and standard deviations of the fadama farmers' attitude towards cost-sharing of the fadama II project. The data show that the farmers expressed positive attitude towards 19 statements out of the 20 statements bordering on cost-sharing arrangement. Among these statements, 10 were negative statements while 9 were positive statements. However, only one statement "cost sharing of the fadama II project has increased farmers' knowledge about farm management $(\bar{x}=1.78)$ " was perceived by the farmers negatively. Specifically, the following positive statements elicited favourable attitude from the farmers: participating in cost sharing of fadama II project is necessary to achieve increased agricultural productivity and income $(\bar{x}=3.69)$; participating in cost sharing in fadama II project is a prerequisite to effective agricultural development $(\bar{x}=3.03)$; cost sharing of fadama II project has increased farmers' voice in the management of the programme $(\bar{x}=$ 3.31); cost sharing in fadama II has made agricultural services to be more relevant and responsive to farmers' needs $(\bar{x}=2.62)$; fadama participating farmers are willing to share in the cost of services considered important to them $(\bar{x}=3.26)$; cost sharing of fadama II project has encouraged farmers to express their rights as information consumers thus ensuring project effectiveness $(\bar{x}=3.18)$; cost sharing of the fadama II project has increased cooperation among the farmers $(\bar{x}=3.69)$; cost sharing in the fadama II project makes extension workers to provide better service to farmers $(\bar{x}=3.07)$ and cost sharing of fadama II project will reduce the financial burden of government and international donor agencies in Nigerian agriculture $(\bar{x}=2.84)$. However, the farmers disagreed with the following negative statements: farmers stand to loose as a result of cost sharing in the fadama II project $(\bar{x}=3.39)$; cost sharing in fadama II project is not the best alternative for funding agriculture $(\bar{x}=2.87)$; most farmers are not willing to participate in the cost sharing due to lack of funds $(\bar{x}=2.72)$; given farmers' poor condition, it is not possible for them to participate in cost sharing of fadama II project sustainably $(\bar{x}=2.95)$; cost sharing of fadama II project does not allow service providers to provide quality service $(\bar{x}=3.36)$; cost sharing in the fadama II project leads to low agricultural output in the programme as many farmers would abscond from the projects $(\bar{x}=3.63)$; cost sharing in fadama II project brings about conflict between farmers and extension workers $(\bar{x}=2.97)$, as well as, that cost sharing in fadama II project has not improved farmers' economic status $(\bar{x}=3.44)$.

These findings show that the majority of the farmers have strong positive attitude towards the cost sharing mechanism of the fadama II programme. More so, the low standard deviations from the mean for all the responses, is an indication that the farmers' individual scores as regards their attitude towards the cost sharing arrangement did not differ from the mean score. This finding agrees with Ozor, Agwu, Chukwuone, Madukwe and Garforth (2007) who noted in their study that farmers were in favour of cost-sharing of agricultural technology delivery in Nigeria. In this study, specific issues which elicited the most favourable attitude from the farmers include "participating in cost sharing of fadama II project is necessary to achieve increased productivity and income" and "cost sharing of the fadama II project has increased cooperation among the farmers". This indicates that the farmers are aware that cost sharing of fadama II project has improved their socio-economic status. 
TABLE 2: Attitude of Farmers towards Cost Sharing of Fadama II Project

S/No Items

1 Participation in cost sharing of fadama II project is necessary to achieve increased agricultural productivity and income.

2* Given our present poor conditions, it is not possible for us to participate in cost sharing of fadama II project substantially

3* Cost sharing in fadama II project brings about conflict between farmers and extension workers

$4 \quad$ Participating in cost sharing of fadama II project is a prerequisite to effective agricultural development

5 Cost sharing in the fadama II project makes extension workers to provide better services to farmers.

$6^{*} \quad$ Cost sharing of fadama II project does not allow service providers to provide quality service

7 Cost sharing of fadama II project has increased farmers' voice in the management of the programme

$8^{*} \quad$ Cost sharing in fadama II project should be restricted only to large scale farmers.

9 Cost sharing in fadama II project has made agricultural services to be more relevant and responsive to farmers' needs

10* Farmers stand to loose as a result of cost sharing in the fadama II project

11* Most farmers are not willing to participate in the cost sharing due to lack of funds

12 Cost sharing of the fadama II project has increased farmers' knowledge about farm management

13 Cost sharing of the fadama II project is necessary for increased cooperation among the farmers

14 Cost sharing of fadama II project will reduce the financial burden of government and international donor agencies in Nigerian agriculture

$15^{*} \quad$ Cost sharing of fadama II project is designed for the benefit of few individuals, hence participation of many farmers is not possible

16 Fadama participating farmers are willing to share in the cost of services considered of importance to them

$17^{*} \quad$ Cost sharing in fadama II project is not the best alternative for funding agricultural programme

18 Cost sharing of fadama II project has encouraged farmers to express their rights as information consumers thus ensuring project effectiveness

19* Participating in cost sharing of fadama II project has not improved farmers' socio-economic status.

20* Cost sharing in the fadama II project leads to low agricultural output in the programme as many farmers would abscond from the project
Mean Standard Remarks Deviation

$2.95 \quad 0.709 \quad$ Disagree

$2.97 \quad 0.869 \quad$ Disagree

$3.03 \quad 0.486 \quad$ Agree

$3.07 \quad 0.561 \quad$ Agree

$3.36 \quad 0.561 \quad$ Disagree

$3.31 \quad 0.506 \quad$ Agree

$3.290 .718 \quad$ Disagree

$2.62 \quad 0.925 \quad$ Agree

$3.390 .668 \quad$ Disagree

$2.720 .822 \quad$ Disagree

$1.780 .419 \quad$ Disagree

$3.690 .485 \quad$ Agree

$2.84 \quad 0.769 \quad$ Agree

$3.180 .709 \quad$ Disagree

$3.260 .562 \quad$ Agree

$2.87 \quad 0.636 \quad$ Disagree

$3.18 \quad 0.462 \quad$ Agree

$3.440 .8001 \quad$ Disagree

$3.630 .525 \quad$ Disagree

${ }^{*}$ Negative statements 
Journal of Agricultural Extension

Vol. 13 (2) December 2009

\section{Level of Participation of Fadama Farmers in the Fadama II Programme}

Data in Table 3 show that farmers engaged in consultative participation with their facilitators in the following activities of the fadama II project, preparation of local development plan LDP $(\bar{x}=2.00)$, carrying out needs assessment $(\bar{x}=2.00)$, preparing list of constraints and opportunities to be addressed through advisory services with respect to fadama enterprise production and marketing $(\bar{x}=1.93)$, identification of priorities of FCA $(\bar{x}=2.00)$, selecting and contracting service providers for technical assistance in the sub project $(\bar{x}=2.30)$, developing, monitoring and evaluation indicators and plan $(\bar{x}=2.01)$, preparation of sub projects proposals for investments $(\bar{x}=2.07)$, preparation, implementation and maintenance sub projects $(\bar{x}=2.00)$, implementation of community based infrastructure $(\bar{x}=2$. 01$)$ and identification of eligible recipients for a matching grant under pilot component $(\bar{x}=2.00)$. Table 3 further showed that there was collaborative participation of the farmers in the following areas: managing of financial resources $(\bar{x}=2.88)$, conflict mitigation measures especially concerning fadama rights $(\bar{x}=2.72)$ and operation and maintenance of fadama investments $(\bar{x}=2.72)$. The Table however showed that farmers were involved in contractual participation with the facilitators in the following activities: plan for training and building the capacity of the FCAs in financial management, community based procurement and impact screening of sub projects $(\bar{x}=1.25)$ and preparing the list of priority public infrastructure sub projects to be funded and executed $(\bar{x}=1.36)$.

From the findings outlined above and the result of the standard deviation values also shown in Table 3, it could be inferred that fadama farmers differed in levels of participation with respect to the different components / activities in the programme. In other words, the farmers' levels of participation were mainly consultative with respect to 10 (ten) of the 15 (fifteen) activities, collaborative for three activities and contractual for two. In other words, the fadama II project under the ADB emphasizes more of consultative participation where key decisions were made by the facilitators while farmers contributed their views. Collaborative participation which recognizes farmers' knowledge thereby creating a climate of knowledge exchange and a strong role in decision making at every stage of the project process (Biggs, 1989b) was witnessed in only three activities. However, empowering farmers to make request which the facilitator and /or project planner is obliged to fulfill in terms of collegial participation was not witnessed in the programme. In other words the fadama farmers were not given the opportunity to analyze decisions in groups or individually without communicating with the facilitators. The implication of this consultative participatory approach as found in fadama II project, where key decisions were made by the facilitators, is that the farmers will not be sufficiently motivated to increase productivity and this does not augur well for the sustainability of the programme. 
TABLE 3: Respondents' Mean Scores on Levels of Participation in Fadama II Project

\begin{tabular}{|c|c|c|c|c|}
\hline S/N & Fadama II activities & $\bar{x}$ & $\begin{array}{l}\text { Standard } \\
\text { deviation }\end{array}$ & Interpretation \\
\hline 1. & $\begin{array}{l}\text { Participation in the preparations of the local } \\
\text { development plan (LDP). }\end{array}$ & 2.00 & 0.000 & Consultative \\
\hline 2. & Carrying out needs assessment. & 2.00 & 0.000 & Consultative \\
\hline 3. & $\begin{array}{l}\text { Preparation, implementation and maintenances of sub } \\
\text { projects. }\end{array}$ & 2.00 & 0.000 & Consultative \\
\hline 4. & Managing of financial resources. & 2.88 & 0.389 & Collaborative \\
\hline 5. & Identification of priorities of individual F.C.A & 2.00 & 0.000 & Consultative \\
\hline 6. & $\begin{array}{l}\text { Preparing list of constraints and opportunities to be } \\
\text { addressed through advisory services with respect to } \\
\text { fadama enterprise production and marketing. }\end{array}$ & 1.93 & 0.260 & Consultative \\
\hline 7. & $\begin{array}{l}\text { Plan for training and building the capacity of FCAs in } \\
\text { financial management, community based procurement } \\
\text { and impact screening of sub projects. }\end{array}$ & 1.25 & 0.434 & Contractual \\
\hline 8. & $\begin{array}{l}\text { Preparing of list of priority public infrastructure sub } \\
\text { projects to be funded and executed. }\end{array}$ & 1.36 & 0.581 & Contractual \\
\hline 9. & $\begin{array}{l}\text { Conflict mitigation measures especially concerning } \\
\text { fadama usurp rights. }\end{array}$ & 2.72 & 0.573 & Collaborative \\
\hline 10 & $\begin{array}{l}\text { Selecting and contracting service providers for technical } \\
\text { assistance in sub project execution. }\end{array}$ & 2.30 & 2.052 & Consultative \\
\hline 11 & $\begin{array}{l}\text { Developing monitory and evaluation indicators and } \\
\text { monitory and evaluation plan. }\end{array}$ & 2.01 & 0.176 & Consultative \\
\hline 12. & Preparation of sub-projects proposals for investment. & 2.07 & 0.260 & Consultative \\
\hline 13. & Operation and maintenance of the fadama investment. & 2.72 & 0.564 & Collaborative \\
\hline 14. & $\begin{array}{l}\text { Implementation of community based infrastructure and } \\
\text { asset acquisition activities. }\end{array}$ & 2.01 & 0.177 & Consultative \\
\hline 15 & $\begin{array}{l}\text { Identification of eligible recipients for a matching grant } \\
\text { under pilot component. }\end{array}$ & 2.00 & 0.000 & Consultative \\
\hline
\end{tabular}

\section{Problems militating against the Effective Implementation of the NFDP in the State}

Data in Table 4 show the major constraints to effective implementation of the NFDP as high production and service cost $(\bar{x}=2.23)$; difficulty in collecting the money from some farmers/high cost of administration $(\bar{x}=2.41$ ) and insufficient credit availability $(\bar{x}=2.18)$. Others include the tendency of highly placed individuals/politicians to hijack the programme by registering personal FRUGs / FCAs $(\bar{x}=2.15)$ and general reluctance on the part of the farmers to pay for services $(\bar{x}=2.11)$.

However the minor constraints in the implementation of NFDP include: inadequate funding support $(\bar{x}=1.96)$; untimely disbursement of inputs $(\bar{x}=1.96)$; untimely counterpart funds from African Development Bank $(\bar{x}=1.59)$; lack of government commitment to policy issues ( $\bar{x}=1.99$ ); poor government commitment to implementation of the cost sharing policy in the programme $(\bar{x}=1.89)$; conflict between service providers in terms of services to be rendered and client groups to serve $(\bar{x}=1.04)$; lack of ready markets to sell the increased output as a result of increased productivity from cost sharing of fadama II project $(\bar{x}=1.09)$; political instability in the country $(\bar{x}=1.05)$; dishonesty /corruption among fadama facilitators 
Journal of Agricultural Extension

Vol. 13 (2) December 2009

( $\bar{x}=1.00)$; poor coordination / planning of the cost sharing programme $(\bar{x}=1.03)$; land tenure system problem $(\bar{x}=1.96)$; poor attitude of extension staff towards farmers participating in the programme $(\bar{x}=1.39)$ and exploitation of farmers by private service providers in the fadama project. $(\bar{x}=1.18)$.

Other problems identified by the respondents through further interaction include: late release of fund to farmers $36.0 \%$, difficulty involved in preparing CDP $19.4 \%$, inadequate acquisition of individual assets $16.5 \%$, lack of money to pay for group shares of the projects $12.9 \%$, lack of cooperation among fadama farmers $6.5 \%$, difficulty in keeping records of activities $1.4 \%$, and lack of farm input $2.9 \%$.

These findings tend to indicate that high production and service costs, difficulty in collecting the money from farmers / high cost of administration, the tendency of highly placed individuals / politicians to hijack the programme by registering personal FRUGs / FCAs, insufficient credit availability, late release of fund to farmers and difficulty involved in preparing CDP are clear issues that need to be addressed if the implementation of the fadama II project is to yield expected results.

TABLE 4: Problems Militating against the Effective Implementation of the NFDP

$\mathrm{S} / \mathrm{N}$ Items $\quad \bar{x} \quad \begin{gathered}\begin{array}{c}\text { Standard } \\ \text { Deviation }\end{array} \\ \text { Devion }\end{gathered}$

1. Land tenure system problem.

$1.16 \quad 1.134$

2. Inadequate funding support from government.

1.96

0.200

3. Untimely disbursement of inputs.

$1.96 \quad 0.200$

4. Untimely counterpart funds from African Development Bank.

$1.59 \quad 0.554$

5. Poor attitude of extension staff towards farmers participating in the $\quad \begin{array}{ll}1.09 & 0.292\end{array}$ programme.

6. Lack of advisory services. $\quad 1.390 .491$

$\begin{array}{lll}\text { 7. High production and service costs. } & 2.23^{*} & 0.396\end{array}$

8. Lack of government commitment to policy issues. $\quad 1.99 \quad 0.176$

9. Poor government commitment to implementation of the cost sharing $\quad 1.89 \quad 0.350$ policy in the programme.

10. Conflict between services providers in terms of services to be rendered $1.04 \quad 0.201$ and client groups to serve.

11. Lack of ready markets to sell the increased output as a result of $\quad 1.09 \quad 0.356$ increased productivity from cost sharing of fadama II project.

12. General reluctance on the part of the farmers to pay for services. $\quad 2.11^{*} \quad 0.557$

13. Difficulty in collecting the money from farmers/high cost of $2.41^{*} \quad 0.608$ administration.

14. Insufficient credit availability. $\quad 2.18^{*} 0.578$

15. Political instability in the country. $\quad 1.05 \quad 0.265$

16. Dishonesty/corruption among fadama facilitators. $\quad 1.00 \quad 0.000$

17. Poor coordination/planning of the cost sharing programme. $\quad 1.03 \quad 0.226$

18. Exploitation of farmers by private service providers. $\quad 1.82 \quad 0.479$

19. The tendency of highly placed individuals/politicians to hijack the $\quad 2.15^{\star} \quad 0.464$ programme by registering personal FRUGs / FCAs.

20. Farmers lack of interest in participating in the cost sharing of fadama $\quad \begin{array}{lll}1.18 & 0.382\end{array}$ project. 


\section{CONCLUSION AND RECOMMENDATIONS}

The result of this study indicated that the majority of the fadama farmers had a very high positive attitude towards cost sharing. The result of this study shows that farmers engaged in consultative participation with their facilitators in ten out of the fifteen listed activities. They were involved through collaborative participation in 3 of the activities while 2 of the activities were on contractual basis. This shows that fadama 11 programme in Kogi State have not brought farmers to the point where they could co-create innovations. The major problems militating against the effectiveness of cost sharing mechanism include late disbursement of services, insufficient credit availability, the tendency of highly placed individuals/politicians to hijack the programme by registering personal FRUGs / FCAs, difficulty in collecting money from farmers and high administrative cost. In view of these, the following recommendations were made:

1. The government, extension administrators and policy makers should popularize the cost sharing strategy in agriculture in other areas of development for the sustenance and stability of funds for development in Nigeria.

2. There is great need to re-visit the issue of farmers participation' which is the hallmark of the fadama programme in order to create a climate of knowledge exchange and a strong role of farmers in decision making at every stage of the project process with the view of empowering farmers to make request which the facilitators will be obliged to fulfill (collegial participation). This is necessary in order to make cost sharing in the on-going fadama III project achievable within the Nigerian context and to bring farmers to the point where they can co-create innovations.

3. The ADB should ensure prompt disbursement of funds (resource materials and services) to further strengthen the existing positive attitude of the farmers towards the fadama project.

\section{REFERENCES}

African Development Fund, (2004), Federal Republic of Nigeria Fadama Development Project. Project Implementation Manual. Agricultural and Rural Development Project OCAR 2.

Agwu, A. E. and Chukwuone, N.A. (2002), Cost Sharing as an Alternative to Financing Agricultural Technology Transfer in Nigeria. A Research Proposal Submitted to the African Technology Policy Studies (ATPS) Network, Narobi, Kenya.

Agwu, A. E. (2004), Factors influencing adoption of improved cowpea production technologies in Nigeria, Journal of International Agricultural and Extension Education, Vol.11, No 1, pp 81-88.

Agwu, A. E. (2005), Attitude of farmers towards the fadama in Okigwe Agricultural Zone, Imo State, Nigerian Journal of Horticultural Science (NJHIS), Vol. 10, pp 65-74.

Agwu, A. E. and Ugwu, P. U. (2008), Farmers' perception of the performance of the National Special Programme for Food Security (NSPFS) in Enugu State, Nigeria. African Journal of Biotechnology. Vol. 7 (12) pp. 1911 - 1921.

Biggs, S. (1989a), A multiple source of innovation model of agricultural research technology promotion, Agricultural Research and Extension Network, Paper No.6, ODI, London. 
Journal of Agricultural Extension

Vol. 13 (2) December 2009

Biggs, S. (1989b), Resource - poor farmer participation in research: agricultural research: a synthesis of experiences from nine national agricultural research system, In: On Farm Client- Oriented Research (OFCOR) Comparative Study Paper, International Service for National Agricultural Research (ISNAR).

Chukwuone, A.N, Agwu, A.E. and Ozor, N. (2006), Constraints and strategies towards effective cost-sharing of agricultural technology delivery in Nigeria: perception of farmers and agricultural extension personnel, Journal of International Agricultural and Extension Education (JAEE), Vol. 13, No 1, pp 29-41.

Heemskerk, W. and Wennink, B. (2005), Stakeholders - driven funding mechanisms for agricultural innovation. Case study of sub-Saharan, Development Policy and Practice, Bulletin 273, Royal Tropical Institute (KIT) -Amsterdam. KIT

Igben, M.S, (1988), Farmers' Capability Profile In: M.S. Igben (ed). The Nigerian Farmer and Agricultural Institution: An Assessment of NISER Ibadan, Nigeria. Pp 67-92.

Kogi State Agricultural Development Project (1998), Programme of 10th Annual OFAR/SPAT Workshop by National Cereal Research Institute, Badeggi at Kogi ADP, Lokoja

Kogi State Fadama Development Office KSFDO (2007), National Fadama Development Project/African Development Bank, ADB Status Report on the National Fadama Development Project (NFDP) in Kogi State as at 28th February, 2007.

National Population Commission (2006), Distribution of the 2006 Population by States in Nigeria.

Onoja, A.F. (2004), History of Second National Fadama Development Project (NFDP-II) and it's Implementation Arrangements. A Paper Presentation on the Occasion Of 2-Day Fadama Sensitization Workshop Organized by Manic Promotions (Nig) Limited in Collaboration with Local Government Service Commission in Lokoja, Kogi State, Nigeria.

Onoja, G.O (2005), Review of past agricultural programmes, Agribusiness Today, Vol. 1, No 7, p 8.

Ozor, N. Agwu, A.E, Chukwuone, N.A., Madukwe, M.C. And Garforth, C.J. (2007), Cost-sharing of agricultural technology transfer in Nigeria: perceptions of farmers and extension professionals, Journal of Agricultural Education and Extension, Vol. 13, No 1, pp 23-37.

Project Coordinating Unit, Federal Ministry of Agriculture and Rural Development PCU-NFDO (2005), Fadama Development Project Poverty Reduction and Increased Productivity through Empowerment, Abuja, Nigeria.

World Bank. (2003a). Fadama II, Project Implementation Manual Vol.1 and Vol. II.

World Bank. (2003b). Project Appraisal Document on A Proposed Credit to the Federal Republic of Nigeria for the National Fadama Development Project. November 18, 2003. 